\title{
On the Development of the Bothriocephalus latus.
}

\section{By M. Bertolus.}

The egg of the Bothriocephalus requires for its complete development a residence of from six to eight months in running water or water frequently renewed. At the moment of the rupture of the ovisac, the egg is composed of a dark brown, resistant, ovoid shell, exactly filled with an amorphous granular mass. Within a month this vitellus divides into cells of 0.015 millim. in diameter; soon afterwards a transparent spot (embryonal spot) makes, its appearance in the centre, and is slowly developed at the expense of the vitellus, the latter at the same time contracting, so as to leave a space between it and the capsule.

In six months the embryonal spot has invaded the whole vitelline mass; at this time the embryonic hooklets make their appearance, and the embryo already manifests some movements of contraction. Lastly, at the end of seven or eight months a sort of operculum separates from the small extremity of the capsule, and furnishes a passage for the embryo.

The embryo consists of two spherical bodies, one within the other. The external body has the form of a hollow sphere 0.045-0.05 millim. in diameter; its wall is about 0.01 millim. in thickness, formed of large prismatic cells pressed against each other, and clothed externally with a quantity of large vibratile flagella of extreme tenuity, very flexible, and 0.010-0.015 millim. in length. By the impulsion of this vibratile apparatus the whole embryonal mass swims rapidly at the moment of its exclusion, turning upon itself ; but in a few hours the movement slackens, ceases soon afterwards, and the ciliary coat seems to disappear.

Within this hollow sphere is another body, likewise of a spheroidal form, moving freely in its envelope, and armed towards one of its poles with three pairs of hooklets perfectly analogous to the six hooklets characteristic of the embryos of Tania. This inner body, formed of very pale nucleated cells $(0.005$ by 0.003 millim.) measures from 0.035-0.04 millim. in diameter.

The hooklets, which are apparently similar in the three pairs, attain a total length of 0.013 millim.; the blade, which is but slightly curved, is about one-third of the total length; the haft, which is straight and very slender, is 0.009 millim. in length; the dental process projects considerably (0.0028 millim.).

The analogy presented by this embryo on the one hand with the embryos of the digenetic Trematoda, and on the other with those of the Tania, seems to indicate clearly that this young parasite is destined to become encysted in the parenchyma of some aquatic animal for its further development.

In connexion with the latter, the author calls the attention of zoologists to a parasitic worm which he considers will prove to be the scolex of the Bothriocephalus latus. This is the Ligula nodosa of Rudolphi, which lives encysted in the conjunctive tissue of various species of the genus Salmo, with regard to which he states that he has ascertained it to be a scolex, of which the so-called cephalic Ann. \& Mag. N. Hist. Ser. 3. Vol. xii. 
portion, which is deeply invaginated in a very narrow caudal portion, presents a complete analogy of form and dimensions with the apparatus of fixation of the Bothriocephalus.-Comptes Rendus, Sept. 21,1863, p. 569 .

\section{On the Structure of the Nervous System in the Gasteropodous Mollusca. By Salvatore Trinchese.}

The types investigated by the author are Helix pomatia, Arion rufus, and Lymnaus stagnalis.

In all the nervous centres of these animals there are-

1. Round or pyriform cells, of variable dimensions, enveloped by a thick sheath of conjunctive tissue.

2. Small cells, of irregularly triangular form, round which no envelope is perceived.

3. Free nuclei like those met with in the grey substance of the cephalorachidian system in the Vertebrata.

In these animals there are no apolar or unipolar cells, and bipolar cells are rare. The cells usually present four prolongations. Each cell emits a prolongation to each of the cells surrounding it, whilst other processes pass between the latter to other cells at a greater or less distance.

The nervous cells generally occupy the periphery of the ganglia. The central portion of the latter is occupied only by nervous fibres and conjunctive tissue. The nervous cells of one ganglion are never all of the same dimensions or of the same form. The largest cells generally form the stratum nearest the periphery, and the cells diminish in size towards the centre of the ganglion. The deepest stratum is formed of very small cells and free nuclei. This arrangement shows that these elements are in a state of continual development.

The two cerebroid ganglia are formed, in their upper part, of large round cells and of pyriform cells. These elements, which are arranged in groups, all emit processes which go to form nerves. The large round cells are placed at nearly equal distances from each other. In the intervals between the round cells there are constantly pyriform cells, of which the processes cross. In the lower region of the two cerebroid masses, very small triangular cells are observed.

At the anterior part of these masses there are, in Helix and Arion, four small ganglia, of the nature of those which have been described under the name of accessory cerebroid ganglia. These are concealed beneath the envelopes of the cerebrum, and can only be seen when the latter are rendered transparent by reagents and the organ is slightly magnified. Of these ganglia the two outer ones must be called optic ganglia, as they give origin to the optic nerves. They consist of free ruclei and of nervous fibres proceeding from the anterior part of the cerebroid masses. The free nuclei alone occupy the outer portion of the ganglion, and the nervous fibres the inner part; the line of separation is very distinct. The two inner ganglia are composed of voluminous cells pressed against each other.

On the course of the nerves connecting the cerebroid masses with the pedal ganglion there is a small ganglion composed of cells united 


\section{$2 \mathrm{BHL}$ Biodiversity Heritage Library}

Bertolus, M. 1863. "On the development of the Bothriocephalus latus." The Annals and magazine of natural history; zoology, botany, and geology 12, 473-474.

View This Item Online: https://www.biodiversitylibrary.org/item/88262

Permalink: https://www.biodiversitylibrary.org/partpdf/65186

\section{Holding Institution}

Smithsonian Libraries

\section{Sponsored by}

Smithsonian

\section{Copyright \& Reuse}

Copyright Status: Public domain. The BHL considers that this work is no longer under copyright protection.

This document was created from content at the Biodiversity Heritage Library, the world's largest open access digital library for biodiversity literature and archives. Visit BHL at https://www.biodiversitylibrary.org. 